\title{
Resenha
}

\section{Metamorfoses do trabalho: crítica à razão econômica}

\section{Débora Dourado*}

GORZ, André. Metamorfoses do trabalho. São Paulo: Annablume, 2003.

ISBN: 85- 7419-364-X

As transformações ocorridas no trabalho ao longo da história da humanidade e a conseqüente "economicização" do mundo são os temas centrais da obra de André Gorz. O texto é constituído da evolução histórica do trabalho, consubstanciando sua análise na censura à razão econômica no mundo moderno. Construído a partir de uma análise crítica fundamentada teoricamente em pensadores-chave (para citar alguns, Marx, Arendt, Habermas e Weber), o texto apresenta sólidos argumentos e proporciona leitura instigante.

O livro está estruturado em três capítulos: Metamorfoses do trabalho, Uma crítica da razão econômica e Orientações e propostas, seguidos de uma seção anexa voltada para propostas e orientações práticas.

No primeiro capítulo, o autor apresenta uma evolução histórica do trabalho, desde a antiguidade, passando pelos moldes manufatureiros, até o formato contemporâneo, cujos efeitos da racionalidade econômica no homem tomam dimensões mais profundas e aniquiladoras. Gorz explora a visão de Marx sobre o trabalho, classificando como utópicos os anseios do comunismo pela comunhão entre a razão e a vida.

Ao abordar a cisão entre trabalho e vida, o autor de Metamorfoses do trabalho explica os efeitos da "esfera da heteronomia" como uma ordem maior e hegemônica na determinação de aspectos que não lhes são próprios. Em seguida, Gorz aborda a desintegração social como contrapartida da cisão funcional no trabalho, trata do fim do humanismo no trabalho - como reversão de todos os valores da vida sobrepujados pela lógica econômica e as pseudo-ressurreições do humanismo, vistas como sofisticações do sistema obtidas por meio de mecanismos reificadores.

O segundo capítulo promove forte crítica à razão econômica, começando pela abordagem das mudanças de valores pelas quais a humanidade passa atualmente. Para o autor, tais alterações são reflexos do intento colonizador e mutilador da razão instrumental sobre o tecido relacional, do qual dependem a integração social. Ainda no segundo capítulo, Gorz articula uma contrapartida entre mercado e sociedade e entre capitalismo e socialismo, apontando para a busca da viabilidade da economia de mercado (sempre ameaçada de colapso) por meio de mecanismos de ajustes como as regulamentações, as taxações e as subvenções, entre outros. Em seguida, o autor discute a necessidade de reaprender a noção de trabalho e de distinguir sua contribuição econômica ou substantiva como forma de resgatar seu sentido próprio.

No terceiro capítulo são apresentadas orientações práticas para a busca de sentido e de construção de uma outra sociedade, através de uma mutação revolucionária que encontraria dificuldades essencialmente políticas de realização. É defendida uma proposta de redução da jornada de trabalho, ressaltando-se as políticas e desafios a serem trabalhados.

* Professora do Departamento de Ciências Administrativas da Universidade Federal de Pernambuco (DCA/UFPE), mestre em administração e doutoranda pelo Programa de Pós-Graduação em Administração da UFPE (Propad/UFPE), além de pesquisadora do Observatório da Realidade Organizacional . E-mail: ddourado@ hotlink.com.br 
Dirigido a sindicalistas e militantes de esquerda, o anexo discute a crise do trabalho e da sociedade. Na conclusão, propõe a diminuição da jornada de trabalho e transformações conceituais na realização do mesmo como meio de ampliar os postos de trabalho e obter mais espaço para o lazer na vida cotidiana.

Em Metamorfoses do trabalho, as reflexões sobre a razão econômica são apresentadas de forma rica e articulada. Suas contribuições extrapolam o campo teórico, atingindo uma dimensão prática. No plano teórico, suas implicações podem ir além das ciências humanas mais tradicionais, alcançando inclusive as ciências sociais aplicadas, impregnadas de modelos gerencialistas e economicistas cuja base está numa visão de mundo unidimensional, de uma lógica estritamente funcional ao sistema. No que se refere ao aspecto prático, André Gorz explora propostas e políticas potencialmente geradoras de transformações da realidade contemporânea do trabalho.

De forma geral, esta obra contribui significativamente para o debate acerca do fenômeno da instrumentalização do homem no trabalho e da perda de sua dimensão substantiva. Sua contribuição é especialmente relevante para uma reflexão sobre a força dominadora do sistema extrapolando enclaves econômicos e alcançando dimensões da vida e do homem.

Portanto, o livro de André Gorz é recomendável para todos aqueles que desejam entender como a lógica econômica invade as esferas da vida e do homem. Nesse sentido, Metamorfoses do trabalho deve ser lido por aqueles que buscam um pensamento crítico e autônomo sobre o mundo, como também pelos que se interessam pelo tema do trabalho, desvinculado das propostas funcionalistas de análise. 